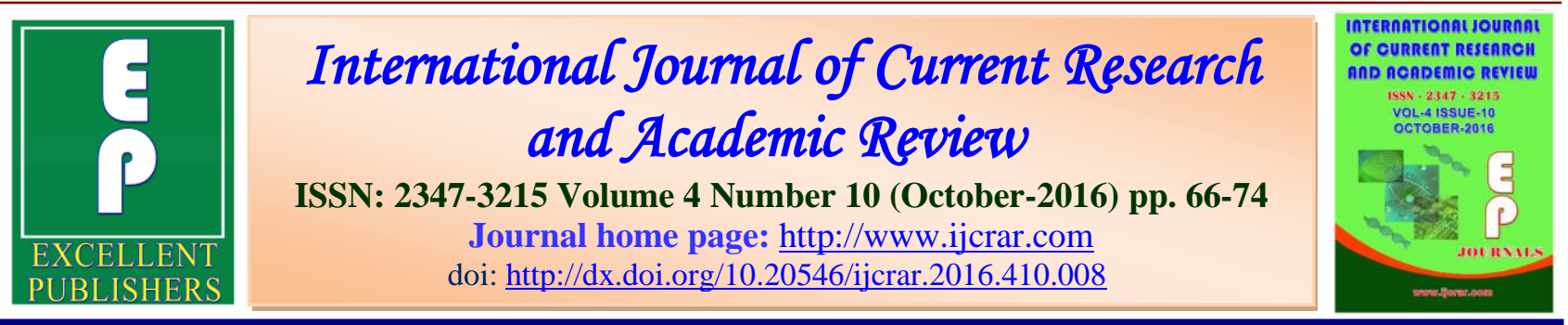

\title{
Detection and Seed Transmission of Alternaria porri in Niger
}

\section{O. Nagaraja $^{1^{*}}$ and M. Krishnappa ${ }^{2}$}

${ }^{1}$ Research Scholar, Department of PG, Studies and Research in Applied Botany, Kuvempu University, Jnana Shyadri, Shankaraghatta-577451, Shivamogga, Karnataka India

${ }^{2}$ Professor, Department of PG, Studies and Research in Applied Botany, Kuvempu University, Jnana Shyadri, Shankaraghatta-577451, Shivamogga, Karnataka India

\section{*Corresponding author}

\begin{tabular}{|c|c|}
\hline KEYWORDS & A B S T R A C $\mathbf{T}$ \\
\hline $\begin{array}{l}\text { Bird seed, } \\
\text { Transmission, } \\
\text { A. porri, } \\
\text { SBM Test, } \\
\text { Leaf blight }\end{array}$ & $\begin{array}{l}\text { Niger is commonly called "birdseed". It is important minor, edible, } \\
\text { traditional oil seed crop in India. The crop is affected by number of diseases. } \\
\text { Among them leaf blight and leaf spot caused by Alternaria porri, the disease } \\
\text { reduces the seed germination and yield up to } 40-40 \% \text {. The present study } \\
\text { concentrated on detection and seed transmission of A. porri in Niger seeds } \\
\text { during kharif seasons-2010-2011. A total of } 132 \text { seed samples were collected } \\
\text { from farmers, retail shops, fields and APMC markets and were subjected to } \\
\text { SBM, PDA, Water agar and 2,4,D methods. Five seed samples showing } \\
\text { higher incidence of } A \text {. porri and other fungi in SBM were selected for seed to } \\
\text { seedling transmission of the pathogen. The results revealed that the kharif - } \\
2010 \text { shows } A \text {. porri (33-52\%) in the SBM method, PDA (11-25\%), Water } \\
\text { agar (6-15\%) and 2,4-D (9-18\%) respectively. The collected seed samples, } \\
\text { fields and farmer's samples show a higher incidence of } A \text {. porri and other } \\
\text { fungi. The SBM method is more superior for isolating the } A \text {. porri and other } \\
\text { fungi than PDA, water agar and 2,4, D methods. The transmission of A. porri } \\
\text { was ( } 12.6 \% \text { ) in kharif } 2010 \text {. In kharif } 2011 \text {, the transmission was }(23.2 \%) \text { in } \\
\text { all the five seed samples. The present study reveals that the disease } \\
\text { transmission is more during kharif-2011 season than } 2010 \text {. The } A \text {. porri is a } \\
\text { causal agent of leaf spot and leaf blight disease of Niger crop. }\end{array}$ \\
\hline
\end{tabular}

\section{Introduction}

Niger [Guizotia abyssinica L (f) Cass.] is commonly called "birdseed" it belongs to the family Asteraceae/Compositae. It is known by various names such as Ramtil or Kalatil in India. It is important minor, edible, traditional oil seed crop in India, cultivated over an area of 0.45 million ha with production of 0.11 million tones and productivity of 2.57 quintals/ha (Annonymous, 2010). It is mainly cultivated in tribal pockets of Gujarat, M.P., Orissa, Maharashtra, Bihar, Karnataka and Andhara 
Pradesh. Niger is a crop of dry areas grown mostly by tribal and interior places as life line of tribal segment. Niger is grown in marginal, intercropping and sub marginal lands. Niger is cultivated over on area of 32700 hactares with a production 6169 tonnes in Karnataka. (Annonymous, 2010). The crop is affected by number of fungal, bacterial, viral and nematodal diseases. The important fungal diseases are Alternaria blight - Alternaria porri \& A. alternata, leaf spot - Cercospora guizoticola, Seedling blight - Alternaria tenuis, seed rot Rhizoctonia bataticola, rust - Puccinia guizotiae, powdery mildew - Sphaerotheca sp, Downy mildew - Plasmapara spp, Tar spot - Phyllosticta spp, Root rot Rhizoctonia solani \& Macrophomina phaseolina and Ozonium wilt - ozonium taxanum (Kandel 2002), Saharan Naresh Mehta and Sangavan (2005), Rangaswamy and Mahadevan (2005). Leaf blight disease is considered to be a major devastating disease to the Niger in India and also reduce the yield and oil quality. In the present work the detection and seed to seedling transmission, their frequency of mortality, recovery of pathogens and its significance were studied.

\section{Materials and Methods}

\section{Scope of the Study}

The present experiment was carried out at Department of Applied Botany, Plant Pathology laboratory, Kuvempu University, Shankaraghatta, Shivamogga Karnataka during kharif season- 2010-2011. Niger seed samples (local variety) collected from different niger growing districts of Karnataka viz., Bellary, Bidar, Chitradurga, Chikmagalore, Davanagere, Dharwad, Gulabarga, Haveri, Mysore, Chamarajanagar, Chikmagalore, Tumkur,
Bangalore-rural, Bangalore-urban, Kolar, Dhrarwad and Raichur districts.

\section{Collection of Niger seed samples}

The seeds of niger were collected from different locations of Karnataka state during kharif-2010. A total of one thirty two samples were collected from fields, farmers, retail shops and APMC markets of Bellary, Bidar, Chitradurga, Chikmagalore, Davanagere, Dharwad, Gulabarga, Haveri, Mysore, Chamarajanagar, Chikmagalore, Tumkur, Bangalore-rural, Bangalore-urban, Kolar, Dhrarwad and Raichur districts of Karnataka. The samples were collected and brought to the plant pathology laboratory of Applied Botany, Kuvempu University and stored in cloth bags room temperature for subsequent studies.

\section{Detection of seed-borne $A$. porri by Seed health test methods (ISTA, 1993)}

\section{SBM Method}

Seed samples were analyzed for the detection of seed-borne fungi by blotter method following ISTA, 1993 with some modifications. In this method, three layers of blotter paper were soaked in sterilized water and placed at the bottom of the Petri plates. One hundred seeds were sterilized in $0.2 \%$ sodium hypochlorite solution for 2 to 3 minutes and seeds taken randomly from each sample and were placed in ten Petri plates (20 seeds per plate). The Petri plates with seeds were then incubated at for seven days in the laboratory. The plates were kept under alternating cycles of $12 \mathrm{hrs}$ light and $12 \mathrm{hrs}$ darkness for seven days. After incubation, the distilled water was added every fourth day to the blotter so as to keep it sufficiently moist. The germination and fungi associated with the seeds were recorded during the incubation period. The 
incubated seeds were examined under stereo binocular microscope to ascertain the presence of fungi. Some times were not apparent even after seven days of the incubation. In such condition, the Petri plates were allowed for further incubation. A temporary slide was prepared from each colony, which could not be identified stereo binocular microscope and examined under Labomed vision 2000 microscope. In fewer cases, the fungi from the incubated seeds were transferred to PDA medium in Petri plates aseptically and incubated under controlled temperature $\left(28 \pm 1^{\circ} \mathrm{C}\right)$ for 3 to 10 days and than examined under Labomed vision 2000 microscope.

\section{PDA Method}

For potato dextrose agar method, 100 seeds were sterilized with $0.2 \%$ sodium hypo chlorite solution for 2 to 3 minutes. Then, the seeds were plated on sterile glass Petri plates containing PDA medium. Twenty seeds per petri plates and than the plates were incubated at $40^{\circ} \mathrm{C}$ in alternating cycles of $12 \mathrm{hrs}$ light and $12 \mathrm{hrs}$ darkness for seven days. After incubation eighth days the seeds were examined by stereo binocular microscope.

\section{Water agar Method}

For agar plate method, 100 seeds were sterilized with $0.2 \%$ sodium hypo chlorite solution for 2 to 3 minutes. Seeds were plated on sterile glass Petri plates containing (2.5\%, i.e., $12.5 \mathrm{gms}$ in $1000 \mathrm{ml}$ of distilled water) water agar medium. These Petri plates were incubated at $25 \pm 2{ }^{\circ} \mathrm{C}$ for seven days. After seven days these seeds were examined under stereo binocular microscope (Neergaard, 1977).

\section{2, 4-D Method}

In this method, 100 seeds were sterilized with $0.2 \%$ sodium hypo chlorite solution for
2 to 3 minutes. The three layers of blotter paper discs were dipped in $0.2 \%$ of 2,4Dichloro Phenoxy acetic acid solution. Twenty seeds were placed equidistantly on moist blotter discs using sterilized forceps in laminar air flow wood under aseptic conditions. The plates were incubated room temperature for seven days. The observations were taken on the seventh day and then seeds were examined under stereo binocular microscope (Limonaard, 1968).

\section{Screening of $A$. porri and other associated mycoflora}

The incubated seeds were screened on eighth day using stereo binocular and labomed vision 2000 compound microscope. The germination, associated fungi were recorded and identified with the help of standard guides and manuals like Barnett (1960), Booth (1977) Sigourd and Funder (1961) Subramanian (1983), Van Arx (1981).

\section{Disease transmission studies in the field}

Among the total seed samples, five samples shows a higher incidence of $A$. porri were selected for disease transmission in experimental plot. The seed samples were sterilized by $2 \%$ sodium hypochloride solution $(\mathrm{NaOCl})$ for 2-3 minutes and in the distilled water before sowing the seeds. Before sowing the seeds the experimental plot were prepared by $10 \times 10$ meter (row and columns) leveled and ploughed. Each sample selected 100 seeds in five replicates. Sterilized seeds were directly sowing in the fields in the month of July-2010. The proper agronomical practices were followed for raising the plants. All the seeds have germinated after 7-10 days. In experimental plots, 15 plants were randomly selected by selecting five plants and leaves randomly in each plant. The severity of the disease was 
assessed by using 0-9 scale and percentage of diseases index was calculated by using the formula (Mayee and Datar, 1986). Seed to seedling transmission of $A$. porri was studied.

$\%$ of disease Sum of individual ratings

Index $(\mathrm{PDI})=$ No. of leaves examined $\mathrm{X}$ Maximum disease grade (9)

\section{Recovery of pathogens from diseased plants}

Seeds were collected from experimental plots in rabi seasons, subjected for seed health testing methods. Again the seeds sown in kharif 2011 season in experimental plot for recovery of pathogens were studied. These seeds yielded the $A$. porri and other fungi. The study shows that $A$. porri are transmitted from seed to seedlings and to the seeds (Thippeswami et al, 2006) .

\section{Result and Discussion}

\section{Seed health testing}

Results of four types of methods used to detect $A$. porri and other mycoflora shown in (Table 1). The standard blotter method were more sensitive in detection of $A$. porri than the PDA, Water agar and 2, 4, Dichloro phenoxy acetic acid mediums. Significant differences in occurrence of seed mycoflora were observed and the results indicated that irrespective of the locations and sources, a total of thirteen fungal species viz., Alternaria porri. Fusarium oxysporum, Alternaria alternata, Cercospora guizoticola, Macrophomina phaseolina, Chaetomium guizotiae, Curvularia lunata, Verticillium dahlia, Cladosporium cladosporioides, Aspergillus flavus, Aspergillus niger, and Aspergillus ochraceus belonging to two genera were detected from local variety of niger seeds. All the fungi decreased germination potential. Out of thirteen fungal species recorded, the occurrence of $A$. porri (33.0 to $52.0 \%$ ) was found predominant in the seed samples analyzed from seventeen districts. The present study revealed that occurrence of seed borne A. porri and other fungi may varied depending up on the location and sources of collection from different farmers and fields. Resume of literature reveals that voluminous work has been carried out all over the world. Some of the noteworthy and recent publications are (Sharma, 1982), Rangeshwaran and Prasad (2000), Rao Raghavendra and Pavgi (1975), Kulkarni and Oblisami (1973), Kolte (1985), Caromona, et al (2006). The present findings are in conformity with earlier reports of oil seed crops, who reported that variation in the occurrence of seed borne $A$. porri and other fungi according to geographic location in niger crop. Choudary and Puttoo (1991), Cook (1955), Bradley and Del Rio (2002), Basuchaudary and Putto (1997) Hans Kendal (2002).

Similarly, visual sporulation of the fungus on the seed was generally heavier in the SBM methods than in Water agar, PDA and 2,4-D methods. However, the standard blotter method was the most effective and revealed a higher incidence of seed infection than the other methods. The collected seed samples, fields, farmers samples show a higher incidence of $A$. porri and other fungi than in retail shops and APMC markets of Karnataka state. This method was also easy quick for recording the presence of $A$. porri on the niger seeds.

\section{Transmission studies in field}

During the field survey the leaf blight and leaf spot, seedling blight of niger was noticed in all visited fields during kharif and rabi seasons in 2010-2011. Symptoms of blight shows, Alternaria blight of niger is 
more serious in Ethiopia as compared to India. The disease appears as concentric rings on the leaves, which turns brown with grey centre later on. As the disease advances, the spots become oval or circular and become irregular in shape. The infected leaves become dry and lead to the defoliation. Further it spreads to other plant parts and results in to premature drying of the plant. The disease is seed borne as well as soil borne. As the plant number is reduced, the disease causes yield losses. The severity of leaf blight and leaf spot and seedling blight diseases was more in kharif2011 then 2010. The present study results revealed that the seeds having $(41.2 \%)$ infection of $A$. porri showed the transmission of $(12.6 \%)$ in Niger. (Average of five seed samples, Table, 2).

\section{Recovery of the pathogen from seeds}

Seed samples were collected from the experimental plot were subjected for seed health testing methods for recovery of diseases transmission. The seeds collected from disease transmitted plants, sown in again during kharif season 2011, infection having $(47.8 \%)$ of $A$. porri showed the (23.2\%) transmission (Average of five seed samples, Table, 3).

Reduction of the seed yield is based on the environmental conditions and the severity of disease symptoms. The mode of seed to seedling transmission of the pathogen is depends on the aggressiveness of the pathogen and environmental conditions like rainfall, temperature, humidity, $\mathrm{P}^{\mathrm{H}}$ and also in growth stages of the crop. Current study revealed that the transmission of the pathogens were more during kharif 2011 than kharif 2010 harvested seeds. But disease transmission is more in kharif 2011 than kharif 2010 seasons. The disease appeared in the first fortnight of July and gradually increased up to November, decline in disease severity with lowering the temperature and relative humidity up to December. Many researchers (Arya et al., 2004) Ashish Kumar Dubey and Tribhuvan Singh (2005), Ashishkumar Dubey and Tribhuvan Singh (2006), Basak (1998), Ghasolia and Jain (2004), Rout (1985), Thippeswamy et al (2006) have recorded the transmission of disease on different oil seed crops, like sesame, safflower, sunflower, soyabean, mustard, ground nut and chilli seeds etc.

The present study reveals that the disease transmission is more during kharif-2011 than 2010 kharif season. The results shows that the kharif-2011 season favors more percentage of pathogens have transmission from the seed to seedling and to the seeds. Because this is environmental factors like rainfall, temperature, humidity, $\mathrm{P}^{\mathrm{H}}$ and also in growth stages of the crops and aggressiveness of the pathogens.

\section{Conclusions}

Results from the present investigation indicated that there was variation in A. porri from one locality to another. Mycoflora of seed varied from place to place due to change in conditions prevailing during seed development, harvesting and storage. $A$. porri was found predominant in the samples analysed from seventeen districts of Karnataka. Detection of seed-borne A. porri and other mycoflora plays an important role in determining the quality and longevity of seeds. Microbial invasion can lead to the rotting, loss of seed viability, germination, quality productivity and yield. It suggests that seeds are major agent of fungal transmission. Seeds should be treated with suitable chemical before sowing to reduce the fungal infection. 
Int.J.Curr.Res.Aca.Rev.2016; 4(10): $x x-x x$

Table.1 Incidence of $A$. porri and other fungi in seed health test methods of Niger.

\begin{tabular}{|c|c|c|c|c|c|c|c|c|c|c|c|c|c|}
\hline \multirow{2}{*}{$\begin{array}{l}\text { Seed health } \\
\text { testing } \\
\text { methods }\end{array}$} & \multicolumn{13}{|c|}{$\%$ seed infection } \\
\hline & A.por & F.oxy & A.alt & M.pha & C.gui & S.rol & C.gui & V.dah & C.cla & N.ory & A.nig & A.fla & R.nig \\
\hline SBM & $* 32.3$ & 11.8 & 17.2 & 4.1 & 21.5 & 2.5 & 4.9 & 3.1 & 4.1 & 5.4 & 6.2 & 19.0 & 3.7 \\
\hline PDA & 14.0 & 3.3 & 8.4 & 2.4 & 7.3 & 0.6 & 8.5 & 1.7 & 3.2 & 1,6 & 5.7 & 6.3 & 4.4 \\
\hline Water agar & 7.0 & 0.0 & 3.3 & 1.3 & 0.6 & 0.0 & 2.3 & 0.0 & 0.3 & 1.9 & 2.8 & 2.1 & 2.9 \\
\hline $2,4-\mathrm{D}$ & 8.9 & 0.5 & 3.8 & 2,1 & 4,2 & 0.8 & 2.5 & 1.9 & 0.5 & 3.9 & 1.8 & 3.7 & 1.0 \\
\hline SD & 11.55 & 5.463 & 6.439 & 3.269 & 6.507 & 1.071 & 2.886 & 1.276 & 1.913 & 1.414 & 2.156 & 7.680 & 1.464 \\
\hline \pm & \pm & \pm & \pm & \pm & \pm & \pm & \pm & \pm & \pm & \pm & \pm & \pm & \pm \\
\hline SE & 5.775 & 2.731 & 3.219 & 0.814 & 3.161 & 0.535 & 1.443 & 0.638 & 0.956 & 1.013 & 1.078 & 3.840 & 0.733 \\
\hline
\end{tabular}

Average values of five samples and 100 seeds per method (five replicates of 100 seeds).

A.por - Alternaria porri, S.rol - Sclerotium rolfsii, F.oxy - Fusarium oxysporum A.alt - Alternaria alternata, M.pha Macrophomina phaseolina, C.gui - Cercospora guizoticola, C.gui- Chaetomium guizotiae, V.dah- Verticillium dahlia, C.claCaldosporium cladosporioides, N.ory-Nigrospora oryzae, A.nig - Aspergillus niger, A.flav - Aspergillus flavus, A.och - Aspergillus ochraceus 
Int.J.Curr.Res.Aca.Rev.2016; 4(10): $x x-x x$

Table. 2 Seed to Seedling transmission A. porri in experimental plot during kharif-2010.

\begin{tabular}{cccccccc}
\hline $\begin{array}{c}\text { Place of } \\
\text { collection }\end{array}$ & $\begin{array}{c}\text { \% of } \\
\text { incidence } \\
\text { in SBM }\end{array}$ & $\begin{array}{c}\text { Germ } \\
\%\end{array}$ & $\begin{array}{c}\text { Pre- } \\
\text { emergence } \\
\text { mortality }\end{array}$ & $\begin{array}{c}\text { Post- } \\
\text { emergence } \\
\text { mortality }\end{array}$ & $\begin{array}{c}\text { \% of } \\
\text { diseased } \\
\text { plants }\end{array}$ & $\begin{array}{c}\text { \% of } \\
\text { healthy } \\
\text { plants }\end{array}$ & $\begin{array}{c}\text { Recovery } \\
\text { of } \\
\text { pathogens }\end{array}$ \\
\hline A. porri & & & & & & A. porri \\
\hline Anekal & 46.0 & 84.0 & 16.0 & 11.0 & 12.0 & 61.0 & 54.0 \\
Pandavapura & 35.0 & 80.0 & 20.0 & 8.0 & 15.0 & 57.0 & 48.0 \\
Sondekolala & 41.0 & 79.0 & 21.0 & 12.0 & 9.0 & 58.0 & 50.0 \\
Vajarahalli & 52.0 & 75.0 & 25.0 & 9.0 & 16.0 & 50.0 & 49.0 \\
Basavanahalli & 33.0 & 81.0 & 19.0 & 9.0 & 11.0 & 40.0 & 38.0 \\
\hline Mean & 41.4 & 79.8 & 20.2 & 9.8 & 12.6 & 53.2 & 47.8 \\
SD & 7.987 & 3.271 & 3.271 & 1.643 & 2.880 & 8.408 & 5.932 \\
SE & 3.572 & 1.462 & 1.462 & 0.734 & 0.758 & 3.201 & 2.652 \\
\hline
\end{tabular}

*Data based on 100 seeds for each sample each sample in five replicates.

Table.3 Seed to Seedling transmission A. porri in experimental plot during kharif-2011.

\begin{tabular}{cccccccc}
\hline $\begin{array}{c}\text { Place of } \\
\text { collection }\end{array}$ & $\begin{array}{c}\text { \% of } \\
\text { incidence } \\
\text { in SBM }\end{array}$ & $\begin{array}{c}\text { Germ } \\
\%\end{array}$ & $\begin{array}{c}\text { Pre- } \\
\text { emergence } \\
\text { mortality }\end{array}$ & $\begin{array}{c}\text { Post- } \\
\text { emergence } \\
\text { mortality }\end{array}$ & $\begin{array}{c}\text { \% of } \\
\text { diseased } \\
\text { plants }\end{array}$ & $\begin{array}{c}\text { \% of } \\
\text { healthy } \\
\text { plants }\end{array}$ & $\begin{array}{c}\text { Recovery } \\
\text { of } \\
\text { pathogens }\end{array}$ \\
\hline A. porri & & & & & & A.porri \\
\hline Anekal & 54.0 & 77.0 & 23.0 & 10.0 & 23.0 & 44.0 & 61.0 \\
Pandavapura & 48.0 & 88.0 & 12.0 & 10.0 & 24.0 & 46.0 & 56.0 \\
Sondekolala & 50.0 & 84.0 & 16.0 & 5.0 & 29.0 & 50.0 & 62.0 \\
Vajarahalli & 49.0 & 80.0 & 20.0 & 8.0 & 21.0 & 51.0 & 55.0 \\
Basavanahalli & 38.0 & 78.0 & 22.0 & 9.0 & 19.0 & 50.0 & 45.0 \\
\hline Mean & 47.8 & 81.4 & 18.6 & 8.4 & 23.2 & 48.2 & 55.8 \\
SD & 5.932 & 4.560 & 4.560 & 2.121 & 3.768 & 3.033 & 6.760 \\
SE & 2.652 & 2.039 & 2.039 & 0.948 & 1.605 & 1.356 & 3.023 \\
\hline
\end{tabular}

*Data based on 100 seeds for each sample each sample in five replicates.

This is due to the environmental factors like rainfall, humidity, temperature, $\mathrm{P}^{\mathrm{H}}$ and also in growth stages of the crop. Seed pathology involves the study of living entities, environmental factor affecting adversely to the seed production and utilization, as well as disease management practices applied to seed. A. porri the causal agent of leaf blight and leaf spot disease of niger crop.

\section{Acknowledgements}

The authors are thankful to the Chairman, DOS in Applied Botany, Kuvempu
University for providing facilities to carry out the present research work.

\section{References}

Anonymous. 2010. Fully revised estimates of principle crops in Karnataka. Directorate of Economics and Statistics, Seshadri Road, Bangalore.

Arya, V.K., Vishunavat, K., Himanshu Negi. 2004. Detection, Location and transmission of seed-borne inoculum of Macrophomina phaseolina in 
charcoal rot in soybean. J. Mycol.

Plant Pathol., 34(2): 233-236.

Ashish Kumar Dubey and Tribhuvan Singh. 2005. Location and transmission of seed-borne inoculum of Fusarium moniliforme in sesame seed. J. Mycol. Plant Pathol., 35: 12-15.

Ashishkumar Dubey and Tribhuvan Singh. 2006. Seed-borne infection of Alternaria alternata and its role in development in sesame. J. Mycol. Plant Pathol., 34(2): 169-172.

Barnett, H.L. 1960. Illustrated genera of imperfect fungi. Burgees publishing company II $^{\text {nd }}$ edition, West Virginia. $1-225$.

Caromona, M.A., Ferrazini, M. and Barreto, D.E. 2006. Tan Spot of wheat caused by Dreschlera tritici-repentis. Detection, Transmission and control in wheat seed. Cereal Res., 34(3): 10431049.

Chandra, S., Narang, M., Srivastava, R.K. 1985. Studies on mycoflora of oil seeds in India: Mycoflora in relation to pre and post emergence mortality. Seed Sci. Technol., 13: 537-541.

Chhata, L.K. 2005. Evaluation of fungicides for the control of Alternaria blight of Castor. J. Mycol. Plant Pathol., 35(1): 88

Hans Kendal. 2002. Niger (Guizotia abyssinica (L.f).Cass) Production in Northwest Minnesota, Extention Service Minnesota, 218-253.

ISTA. 1993. International Seed Testing Association. The germination test. International rules for seed testing. Seed Sci. Technol., 21: 152.

Kabeere, F., Hampton, J.G. and Hill, M.J. 1997. Transmission of Fusarium graminearum (Schwabe) from Maize seeds to seedlings. Seed Sci. Technol., 25: 245-252.

Kolte, S.J. 1985. Diseases of Annual Edible Oilseed Crops. Vol. III; sunflower, safflower and niger seed Diseases. CRC Press Inc., Florida, USA. 135.

Kulkarni, J.H. and Oblisami, G.H. 1973. The mycoflora of stored Niger seeds. Madras Agri. J., 60: 1879-1881.

Kulkarni, J.H. and Oblisami, G.H. 1973. The mycoflora of stored Niger seeds. Madras Agri. J., 60: 1879-1881.

Limonard, J. 1968. Ecological aspects of seed health testing. International Proceedings of Seed Testing Association, 33: 1-8.

Mayee, C.D. and Datar, V.V. 1986. Technical bulletin-1. Marathwad Agricultural University, Parbhani. Phytopathometry, 46.

Mukerwar, P.M. 1992. Seed transmission of Alternaria macrospora in Gossypium arboreum. Seed Res., 20(2): 166-167.

Neergaard, P. 1977. Seed pathology, Vol. I \& II. Mac Millan, London. 850 \& 250.

Prasad, N.V.K. 1988. Studies on the Alternaria leaf blight of safflower (Carthamus tinctorius L.). Ph.D. Thesis, Banaras Hindu University, Varanasi, India.

Rangaswamy, G. and Mahadevan. 2005. Diseases of crop plants in India. $4^{\text {th }}$ ed., Prentice Hall of India Pvt. Ltd., New Delhi-110001.

Rout, J.G. 1985. Location of Alternaria helianthi in sunflower seed and transmission from to seed to plant. Phytopathol. Notes, 38: 522.

Saharan, G.S., Naresh Mehta and Sangavan, M.S. 2005. Diseases of Niger diseases, of oil seed crops, Indus. Publishing Company, Fs-5, Tagore Garden, New Delhi - 110 027, 475-479.

Shekarappa, G. and Patil, P.V. 2001. Chemical control of leaf blight of sesame caused by Alternaria sesame. Karnataka J. Agri. Sci., 14(4): 11001102.

Shukla, B.N. and Singh, B.P. 1972. Effect of fungicides on seed-borne pathogens of 
Niger (Guizotia abyssinica (L.f).Cass), Phytopathol. Notes, 3: 231-232.

Sigourd and Funder. 1961. Practical mycology, manual for identification of fungi. A.W. Broggers, Bltrykkeri, AISOSIO-Norway. 1-145.

Subramanian, C.V. 1983. Hypomycetes Taxonomy and Biology. Academic Press, London, Vol. I \& II. 1-930.

Thippeswamy, B., Krishnappa, M. and Chakravarthy, C.N. 2006. Location and transmission of Alternaria solani and Fusarium oxysporum in tomato. Asian J. Microbiol. Biotechnol. Enviviron. Sci., 8(1): 45-48.

Van Arx, J.A. 1981. The genera of fungi sporulating in pure culture. J.Cramer Inder. A.R. Ganter Verlag, Kommanditgesellsehaff. F.L-9490. VADUZ.

\section{How to cite this article:}

Nagaraja, O., and Krishnappa, M. 2016. Detection and Seed Transmission of Alternaria porri in Niger. Int.J.Curr.Res.Aca.Rev.4(10): 66-74.

doi: http://dx.doi.org/10.20546/ijcrar.2016.410.008 